\title{
ORGANIZATION AND LEGISLATIVE REGULATION OF REHABILITATION ASSISTANCE TO PARTICIPANTS OF JOINT FORCE OPERATIONS
}

DOI: $10.36740 /$ WLek202006138

\author{
Vyacheslav M. Zhdan, Oleksandr D. Havlovskyi \\ UKRAINIAN MEDICAL STOMATOLOGICAL ACADEMY, POLTAVA, UKRAINE
}

\begin{abstract}
The aim of our study was to investigate the mechanisms of rehabilitation, primarily medical, of participants in the armed conflict in the eastern regions of Ukraine (anti-terrorist operation/Joint Forces operation).

Materials and methods: Standard statistical methods were used to accomplish these tasks - bibliosemantic and content analysis methods. So, as can be seen from the conducted research, in Ukraine there is a legal regulation of the process of providing rehabilitation assistance (social, psychological, medical) for the participants of armed conflict in the eastern regions of Ukraine (ATO / JFO).

Review: It should be noted separately that the organizational mechanisms for the provision of rehabilitation are constantly improving: introduction of the International Classification of Functioning, Restrictions of Life and Health and the International Classification of Functioning, Restrictions of Life and Health of Children and Adolescents in Ukraine introduced the qualification characteristics of rehabilitation specialists and rehabilitation specialists, physical therapist, ergotherapist, physical therapist assistant, ergotherapist assistant. Conclusions: It was also determined that despite the constant improvement of the organizational and regulatory frameworks for the provision of rehabilitation, there is a problem of the lack of unified protocols for the provision of medical rehabilitation - there is only a protocol of measures for post-traumatic stress disorder. Available and applicable the "road map" of providing of medical assistance, reparative treatment and rehabilitation measures in health care facilities for ATO participants.
\end{abstract}

KEY WORDS: medical rehabilitation, anti-terrorist operation, Joint Force operation, organization or rehabilitation

Wiad Lek. 2020;73(6):1272-1278

\section{INTRODUCTION}

The current situation in the eastern regions of Ukraine constantly requires from our state resources - both material and human. An increasing number of Ukrainians are forced to take up arms in order to protect their homeland and promote a peaceful situation $[1,2]$. Despite all measures taken by the government of the country and the world community (Minsk negotiations, sanctions and restrictions on the aggressor and other measures), the armed conflict continues and constantly leads to human casualties among Ukrainian civilians and military men [3]. It should be noted that in addition to irreversible human losses, there is a large amount of financial, social and psychological damage to military personnel who take part in the defense of the state $[4,5]$. The problem of restoration and preservation of health, as well as of working capacity of the persons who have faced military actions in Ukraine is very urgent today $[6,7,8,9]$.

The basic concepts of rehabilitation, developed by WHO experts, focus on a system of measures aimed at the quickest and most complete restoration of a patient's physical, psychological and social status in order to actively integrate the patient into society with a view to achieving possible social and economic independence for him. In the conditions of constant increase of the number of participants of hostilities, conducting a complex of measures for rehabilitation treatment and further social integration of veterans of the anti-terrorist operation in the society is one of the priority directions of the social policy of the state $[10,11]$.

\section{THE AIM}

The aim of our study was to investigate the mechanisms of rehabilitation, primarily medical, of participants in the armed conflict in the eastern regions of Ukraine (anti-terrorist operation/Joint Forces operation).

\section{MATERIALS AND METHODS}

Standard statistical methods were used to accomplish these tasks - bibliosemantic and content analysis methods.

\section{REVIEW AND DISCUSSION}

The issue of obtaining the status of a participant in the anti-terrorist operation. It is the responsibility of the state and the government to provide of social protection of the members of the anti-terrorist operation (Joint Forces operation(JFO)) and they do it $[12,13]$. 


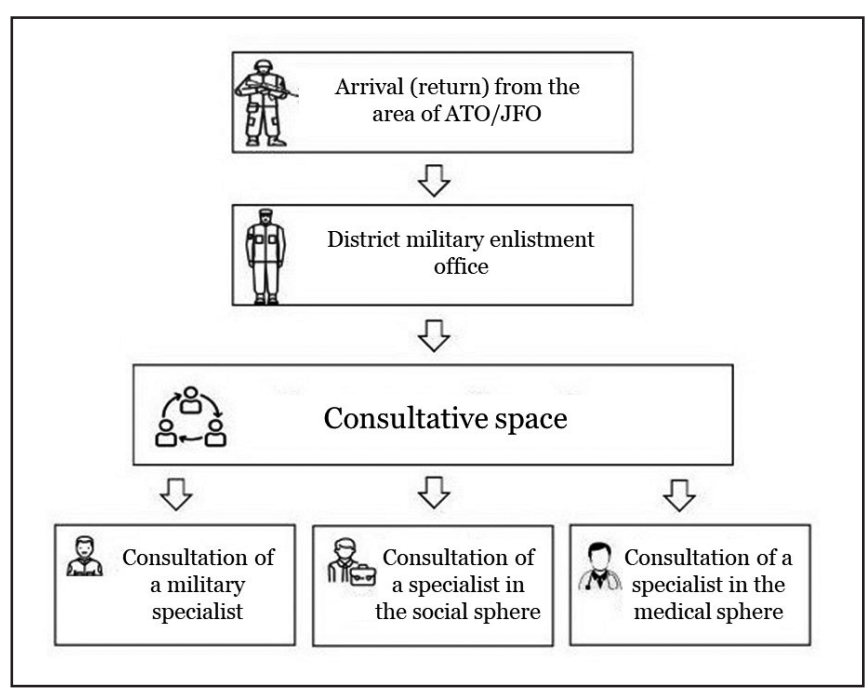

Fig. 1. Scheme of determining the need of the ATO/JF0 participant in the rehabilitation program.

According to $6^{\text {th }}$ Article of the Law of Ukraine "On the Status of War Veterans, Guarantees of their Social Protection" [14], military personnel (reservists, conscripts) and workers of military formations of Ukraine, who defended the independence, sovereignty and territorial integrity of Ukraine and participated directly in anti-terrorist operation (ATO), ensuring its carrying out, being directly in areas of carrying out the ATO, and also employees of the enterprises, establishments and the organizations which were involved and participated directly in ATO in areas of its implementation.

Procedure for granting and denying the status of a participant of hostilities to persons who defended the independence, sovereignty and territorial integrity of Ukraine and participated directly in the anti-terrorist operation, ensuring its realization or in the implementation of national security and defense measures, repulsion and restraint of armed aggression of the Russian Federation in Donetsk and Lugansk regions, ensuring their implementation was approved by the Cabinet of Ministers of Ukraine of August 20, 2014 № 413. The legislative changes from February 19, 2020 to this Resolution were introduced the procedure for obtaining of this status by volunteers who participated directly in the ATO/JFO. $[15,16]$.

Rehabilitation and readaptation of participants of ATO/ JFO. The Decree of the Cabinet of Ministers of Ukraine of December 5, 2018 №1021 approved the State target program for medical, physical rehabilitation and psychosocial re-adaptation of the victims of the Revolution of Dignity, participants of the anti-terrorist operation and persons who participated in the implementation of national security and defense measures, curbing the armed aggression of the Russian Federation in Donetsk and Luhansk regions, ensuring their implementation, for the period up to 2023 [17].

Complex rehabilitation of disabled military personnel and combatants (ATO/JFO participants) provides for statutory guarantees and aspects of rehabilitation and adaptation, including: medical rehabilitation; prosthetics and orthotics, provision of technical means of rehabilitation; psychological rehabilitation; social rehabilitation; vocational rehabilitation $[14,18,19]$.

A generic algorithm for determining need and providing rehabilitation assistance is presented in Figure 1.

After counseling, the individual needs of each demobilized soldier are determined, and a plan and a clear program of rehabilitation activities are developed accordingly.

At the level of a military specialist, the task is to identify military personnel who have a morbid mental reaction and refer them to health care facilities. Particular attention is paid to the diagnosis of acute reactions to stress, the detection of signs of physical and mental fatigue, severe asthenisation, mental maladaptation and the like. It is obligatory to carry out specialized individual psychological counseling on problems of alcohol and drug abuse, asocial behavior, problems in acute psychological crises, etc [20].

Speaking about social problems, it is established that different types of trainings - specialized, professional, communicative, social and psychological, etc. are very effective

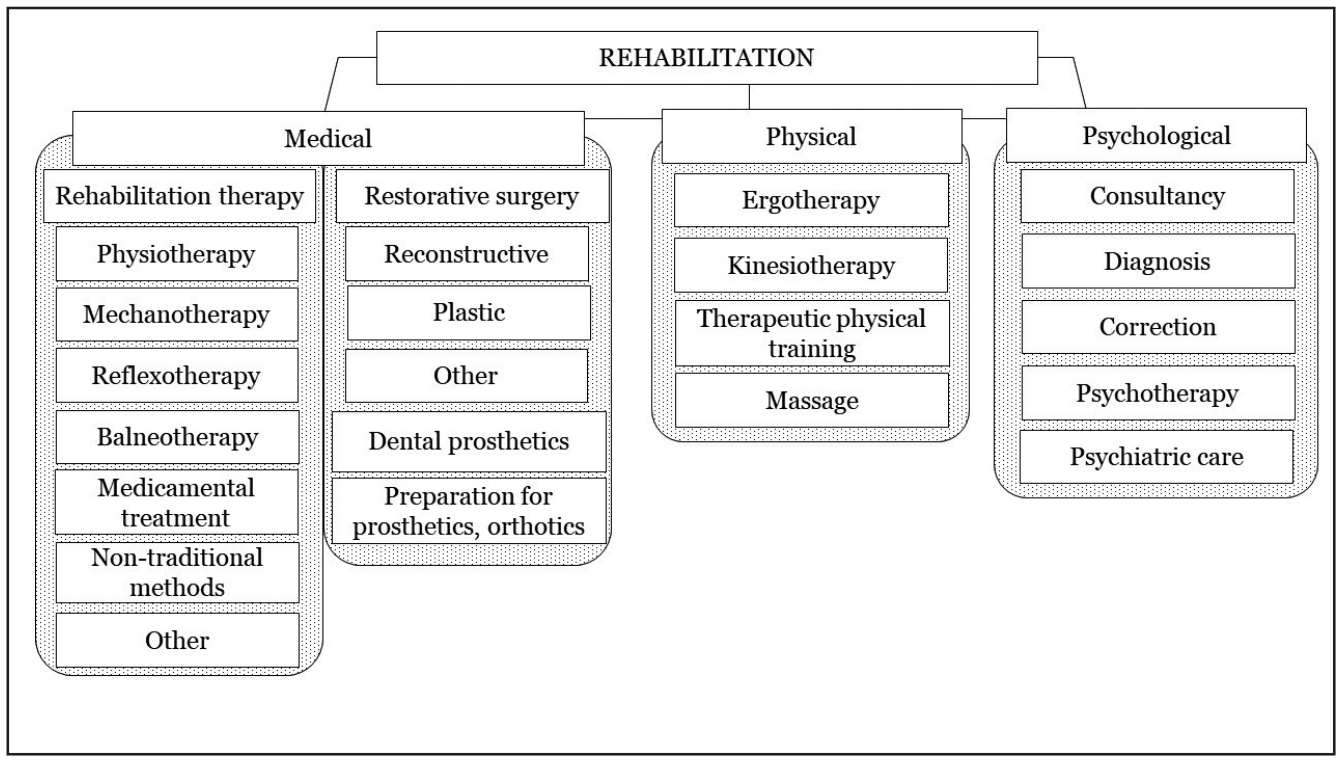

Fig. 2. The types of medical rehabilitation. 


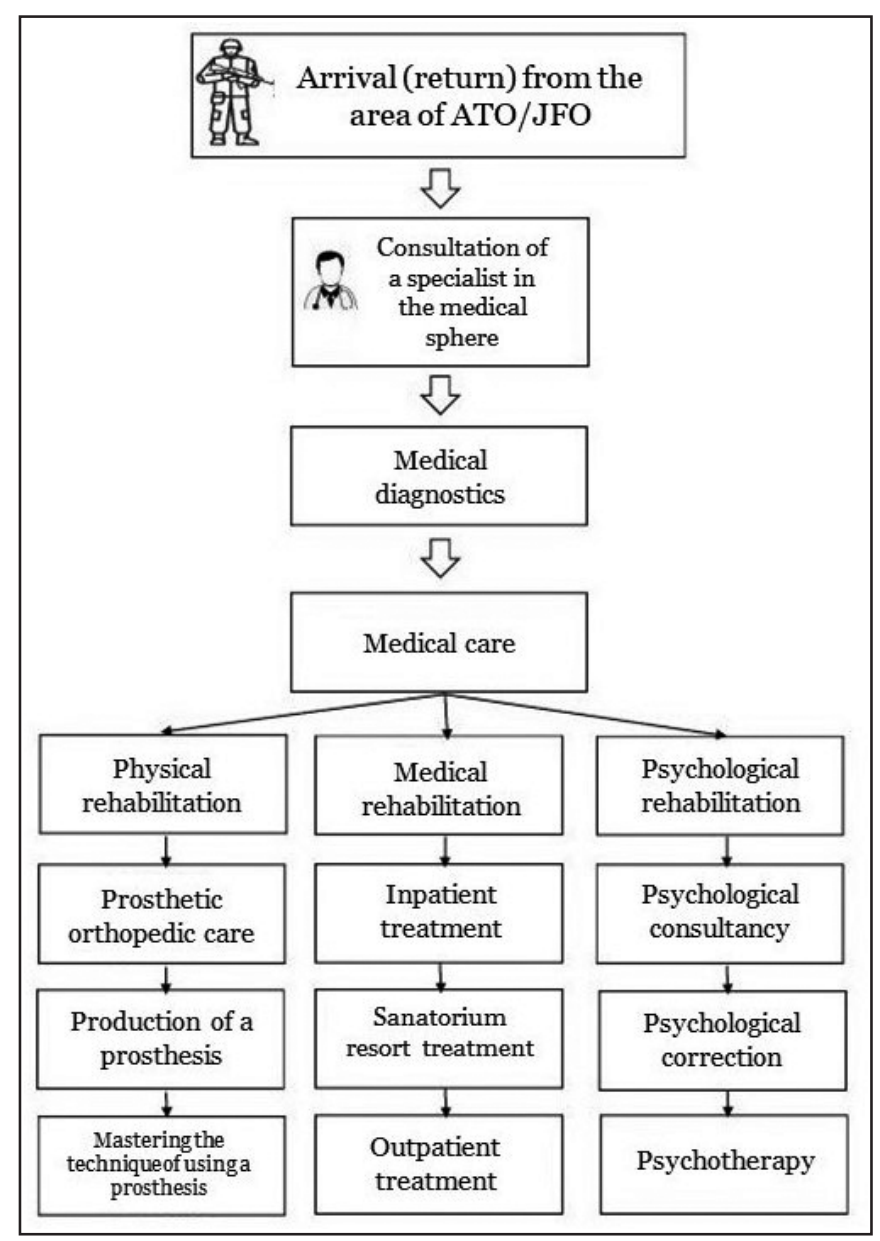

Fig. 3. The scheme of choice of the rehabilitation program.

in the development of the rehabilitation complex. When conducting such activities, social services professionals should pay attention to the creation of a clear algorithm for structural elements, focusing on adaptive issues with emphasis on specific features, principles and rules, a set of methods and techniques. Family therapy, which provides individual and family counseling as well as group psychotherapy separately with military personnel and separately with their family members, aimed at correction of interpersonal relationships in family and family relations, is very important and valuable for effective rehabilitation of the participants of the fighting $[21,22]$.

Events in the area of anti-terrorist operation have a strong impact on the mental and, often, physical health of its participants. Analyzing the causes that lead to the loss of health and the need for rehabilitation measures, we can say that the main part consists of various post-traumatic conditions and disorders: traumas, injuries, as well as psychological disorders (post-traumatic stress disorder, psychological disorders, etc.). It should also be noted that in addition to post-traumatic health loss, often persistent health loss (disability) is caused by various infectious and parasitic diseases, as well as by various conditions of the therapeutic profile: pathology of blood and hematopoietic organs, endocrine disorders, diseases of the nervous system, the eye and its appendix, the ear and the mastoid process, the circulatory system, the respiratory system, the digestive system, the genitourinary system [24].

Based on the above, it should be noted that along with sociological and psychological rehabilitation special attention should be paid to the organization of medical rehabilitation. Medical rehabilitation is a system of curative measures aimed at restoring impaired or lost functions of the body of the person, to identify and activate the compensatory capacity of the body in order to provide conditions for the person to return to normal life, to prevent complications and relapses of the disease.

The importance of medical rehabilitation for armed conflict participants was underlined by Presidential Decree No.150 of March 18, 2015, which required that steps be taken to introduce a mandatory medical examination of the health status of demobilized anti-terrorist operation participants [25]. The Cabinet of Ministers issued the Order "On Approval of the Plan of Measures for Medical, Psychological, Professional Rehabilitation and Social Adaptation of the Participants of the Anti-Terrorist Operation" No. 359-r dated 31.03.15, which provides for mandatory medical examination of military personnel after participating in the ATO [26]. According to Article 35-5 of the legislation of Ukraine on health it is determined that medical rehabilitation assistance is provided only after recognition of a person with a disability in accordance with the established legislation and is carried out according to medical indications in a certain order and ensures the formation of state health policy [27].

To improve the mechanism of medical rehabilitation and increase its efficiency in Ukraine, a plan of measures for implementation of the International Classification of Functioning was developed and implemented, as well as the qualification characteristics of most specialists of rehabilitation: physician of physical and rehabilitation medicine, physical therapist, ergotherapist, assistant therapist. The Ministry of Health of Ukraine has drafted the Concept of Reform of the Medical and Social Expertise, which is changing the approach to disability - medical rehabilitation services should start from the moment of a health problem, and not only after establishing the disability status. This approach should increase the level of recovery of body functions to the maximum possible level of recovery. Medical rehabilitation is included in the program of medical guarantees in accordance with the Law of Ukraine on "On State Financial Guarantees of Public Health Services" [19].

It should be noted that medical rehabilitation is a heterogeneous concept and has different directions and approaches in its structure (Fig. 2).

The process of medical rehabilitation involves the formation of multidisciplinary rehabilitation teams that, working mainly within the framework of evidence-based rehabilitation, will focus not only on the treatment and elimination of the disease by all possible traditional medical methods, but also on the elimination of activity limitations due to that disease or injury.

Generally, a medical rehabilitation scheme for demobilized soldiers returning from the ATO/JFO Area involves 
conducting a comprehensive medical examination, followed by the establishment of a diagnosis, followed by the provision of appropriate medical care, the results of which determined the rehabilitation mechanisms (Fig.3).

The following rehabilitation periods are identified in the planning of rehabilitation activities:

- stabilization period - focused on stopping the progression of the damaging agents and stopping the deterioration of body functions;

- mobilization period - efforts focus on restoring the functional state of the organism or on empowerment in the altered state of damage;

- supporting period - consolidation of the results achieved in the previous stages and prevention of their reverse development.

The leading methods of medical rehabilitation are rehabilitation therapy and surgery with subsequent (if it necessary) prosthetics. Restorative therapy is carried out, first of all, with the help of standard medicament treatment.

In carrying out of medical rehabilitation, the following tasks are put to specialists:

- restoration of health status;

- elimination of pathological process;

- prevention of complications and recurrences;

- restoration or, if impossible, partial or full compensation of lost functions;

- adaptation to household and professional production loads;

- prevention of permanent disability (early onset) or worsening of the already established degree of disability. [28]

Specialists in medical rehabilitation: physicians, physical therapists, ergotherapists, traumatologists, neuropathologists, surgeons or other specialists (depending on the nature of the diseases of the persons to be rehabilitated), nurses [29].

In medical rehabilitation various and unequal means are used in different stages. The complex of rehabilitation therapy includes various medical treatment, various types of hardware physiotherapy, hydrotherapy, climatotherapy, physical therapy, mechanotherapy, therapeutic massage, ergo and kinesitherapy, psychotherapy and psychological correction, diet therapy, non-traditional therapy, diet therapy, phytotherapy, etc.), speech correction, occupational therapy, rehabilitation mode [30].

Medical rehabilitation usually begins with active treatment, which is dominated by pathogenetic drug therapy or surgical treatment aimed at eliminating or reducing the activity of the pathological process.

Standard drug treatment is gradually being replaced by supportive pharmacotherapy and various non-drug therapies. The role of non-drug rehabilitation is gradually increasing in the next stages of rehabilitation and is intended to accelerate recovery, achieve long-term remission, restore disability, prevent disability and return the patient to society (Fig. 4).

Medical rehabilitation can be carried out according to the appropriate rehabilitation programs (Fig. 4) according

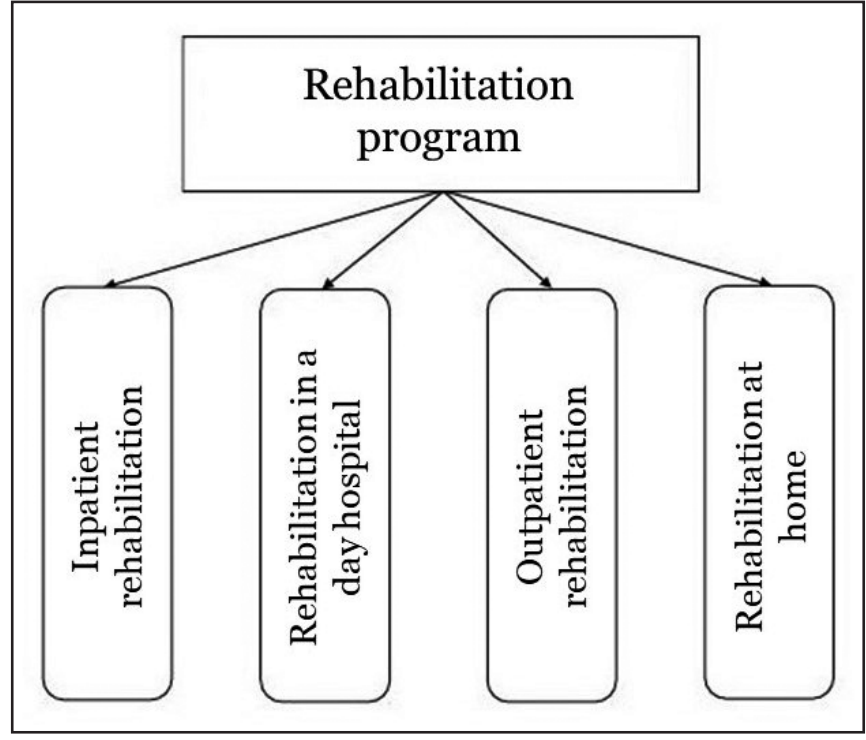

Fig. 4. Types of medical rehabilitation programs.

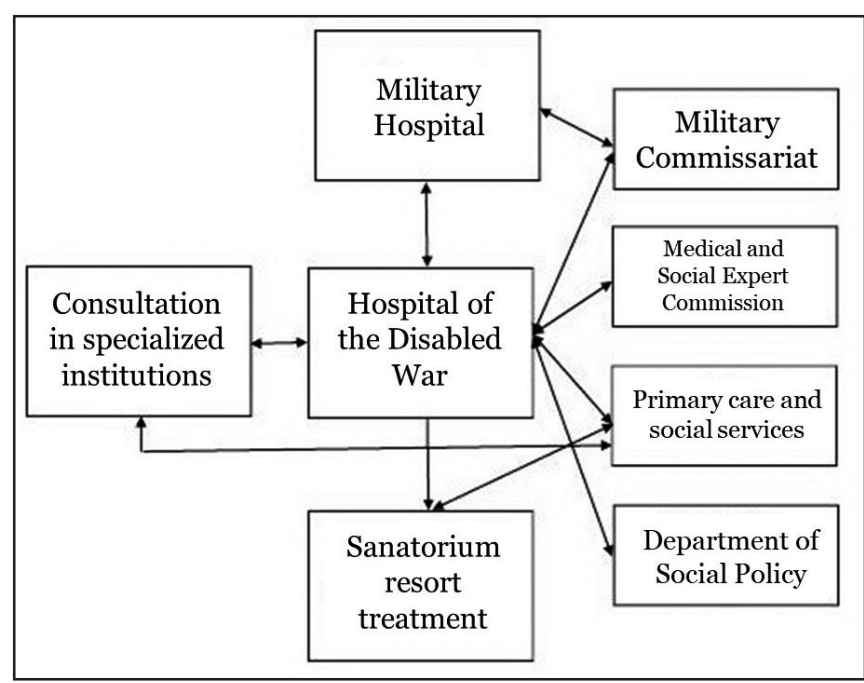

Fig. 5. Scheme ("road map") of providing of medical assistance, reparative treatment and rehabilitation measures in health care facilities for ATO participants, incl. demobilized.

to which treatment regimen is selected. The most common non-medication remedies are adherence to the appropriate regimen. Guard mode, which involves depriving the patient of excessive mental and physical activity. In hospitals when undergoing treatment use: bed mode (severe and extended bed), semi-bed (within the ward) and free (general) regimens. In sanatoriums and during outpatient clinic treatment, patients are prescribed sparing, sparingly-training, training, and more recently - intensively training regimes.

Protocols on standardization of medical care for post-traumatic stress disorder (PTSD), approved by the Order of the Ministry of Health "On approval and implementation of medical and technological documents for standardization of medical care for post-traumatic stress disorder" No. 121 of 23.02.16, which is the only document that is approved servicemen. However, the protocols regulate the highly specialized issue of PTSD and the provision of assistance to 
military personnel in institutions subordinate to the Ministry of Health. The procedure for providing assistance with other diseases and disorders that may befall a person who has gone through combat has not yet been established by law [31].

Departments of health care of regional administrations have developed and implemented a "road map" of medical rehabilitation of servicemen, employees of the Armed Forces of Ukraine, National Guard, and other law enforcement agencies that participated in the anti-terrorist operation (Fig. 5).

Based on this "roadmap" and based on medical history, analysis and instrumental findings, a doctor may recommend medical, physical or psychological rehabilitation at a regional hospital or hospital in subordinate of the Ministry of Armed Forces of Ukraine (there are 30 such institutions in Ukraine). The decree of the Ministry of Defense of Ukraine No. 703 of 09.12.2015 approved the lists of medical indications and contraindications to sanatorium treatment and medical rehabilitation in the health resorts of the Armed Forces of Ukraine.

\section{CONCLUSIONS}

So, as can be seen from the conducted research, in Ukraine there is a legal regulation of the process of providing rehabilitation assistance (social, psychological, medical) for the participants of armed conflict in the eastern regions of Ukraine (ATO / JFO). It should be noted separately that the organizational mechanisms for the provision of rehabilitation are constantly improving: introduction of the International Classification of Functioning, Restrictions of Life and Health and the International Classification of Functioning, Restrictions of Life and Health of Children and Adolescents in Ukraine introduced the qualification characteristics of rehabilitation specialists and rehabilitation specialists, physical therapist, ergotherapist, physical therapist assistant, ergotherapist assistant.

It was also determined that despite the constant improvement of the organizational and regulatory frameworks for the provision of rehabilitation, there is a problem of the lack of unified protocols for the provision of medical rehabilitation - there is only a protocol of measures for post-traumatic stress disorder.

Available and applicable the "road map" of providing of medical assistance, reparative treatment and rehabilitation measures in health care facilities for ATO participants.

\section{REFERENCES}

1. Topol 0. V. Soczi’al’no-psikhologi’ chna reabi’ li’ taczi’ya uchasniki 'v antiteroristichnoyi operaczi yi. [Socio-psychological rehabilitation of participants of anti-terrorist operation]. Bulletin of Chernihiv National Pedagogical University. 2015; 124: 230-233. (In Ukrainian).

2. Koczyuruba R. M. Soczi`al`no-psikhologi 'chna reabi`li’ taczi ya uchasniki'v antiteroristichnoyi operaczi`yi. [Socio-psychological rehabilitation of participants of anti-terrorist operation]. Topical Problems of Designing, Manufacturing and Operation of Weapons and Military Equipment: Proceedings of the All-Ukrainian Scientific and Technical Conference, Vinnitsa, May 17-19 2017. Vinnitsa, 2017. p.183-187. (In Ukrainian).
3. Wittke C. The Minsk Agreements - more than "scraps of paper"? East European Politics. 2019; 35 (3): 264-290.

4. Visochina I. L., Moroz S.M., Vasilevska I.V. et al. Osobennosti mediczinskogo soprovozhdeniya uchastnikov ATO na pervichnom urovne okazaniya mediczinskoj pomoshhi. [Features of medical support of ATO participants at the primary level of providing medical care]. Medical perspectives. 2016; XXI. 2(1):35-39. (In Ukrainian).

5. Reabi Mojsa B., edited by 0. Pavlichenko, 0. Martynenko. 'li taczi ya zhertv konfli 'ktu. Chi proponuye derzhava shhos', kri' m vstanovlennya i' nvali' dnosti' ta milicz'? [Rehabilitation of the victims of the conflict. Does the state offer anything other than disability and crutches?]. Ukrainian Helsinki Human Rights Union. K.; 2018, 64 p. (In Ukrainian).

6. Agaev N.A., et al. Algoritm roboti vi js' kovogo psikhologa shhodo psikhologi' chnogo zabezpechennya profesi 'jnoyi di yal 'nosti' osobovogo skladu Zbrojnikh Sil Ukrayini (metodichni' rekomendaczi yi) [Algorithm of work of military psychologist on psychological support of professional activity of personnel of Armed Forces of Ukraine (methodical recommendations)]. K.: Humanitarian Problems Research Center of the Armed Forces of Ukraine; 2016, 147 p. (In Ukrainian).

7. Pro skhvalennya Konczepczi yi rozvitku sistemi gromads 'kogo zdorov'ya [About Approval of the Concept of Public Health System Development]: Ordinance of the Cabinet of Ministers of Ukraine from 30.10.2016 p. № 1002-p URL:https://zakon.rada.gov.ua/laws/show/1002-2016\%D1\%80. (In Ukrainian).

8. Didach V., Vasylenko L., Lavreniuk V., Stanislav I. Vikonannya Planu zakhodi' v shhodo medichnoyi, psikhologi' chnoyi, profesi jnoyi reabi' li taczi'yi ta soczi'al'noyi adaptaczi yi uchasniki'v antiteroristichnoyi operaczi yi: anali tichnij zvi t. [Implementation of the Plan of Measures for Medical, Psychological, Professional Rehabilitation and Social Adaptation of Participants in the AntiTerrorist Operation: An Analytical Report]. Kyiv: Public organization «All-Ukrainian human rights organization« Legal hundred»; 2017, 44 p. (In Ukrainian).

9. Osnovi reabi li taczi jnoyi psikhologi yi: podolannya nasli dki ` krizi. Navchal' nij posi 'bnik. Tom 1. [Fundamentals of rehabilitation psychology: overcoming the effects of the crisis. Tutorial. Volume 1]. Київ; 2018, 208 р. (In Ukrainian).

10. Kokun 0.M. et al.Psikhologi' chna robota z vi js' kovosluzhbovczyami - uchasnikami ATO na etapi` vi' dnovlennya: Metodichnij posi bnik. [Psychological work with military personnel - participants of anti-terrorist operation during the recovery phase: A manual]. K.: Humanitarian Problems Research Center of the Armed Forces of Ukraine; 2017, 282 p. (In Ukrainian).

11. BrindikovYu. L. Teori' ya ta praktika reabi li’ taczi yivi’ js' kovosluzhbovczi 'vuchasniki v bojovikh di' j v sistemi' soczi al' nikh sluzhb [Theory and Practice of Rehabilitation of Servicemembers in the System of Social Services]: the dissertation for the degree of Doctor of Pedagogical Sciences in the specialty 13.00.05 / Khmelnytsky National University of the Ministry of Education and Science of Ukraine, Khmelnytsky, 2018. 559 p. (In Ukrainian).

12. Gayda I. M. Mediko-soczi al 'ne obgruntuvannya udoskonalennya sistemi medichnoyi reabi 'li taczi yi vi js' kovosluzhbovczi 'v na regi onal' nomu ri' vni' [Medico-social justification for improving the system of medical rehabilitation of servicemen at the regional level]: the dissertation for the degree of Candidate of Medical Sciences in the specialty 14.02.03 / Ukrainian Military Medical Academy of the Ministry of Defense of Ukraine. Uzhgorod National University of the Ministry of Education and Science of Ukraine, Kyiv, 2018. 180 p. (In Ukrainian). 
13. Yavorovenko, 0. B. Potrebi uchasniki 'v antiteroristichnoyi operaczi yi z i'nvali' dni styu vnasli' dok somatichnoyi patologi' yi v tekhni' chnikh zasobakh reabi 'li taczi yi ta virobakh medichnogo priznachennya. [Needs of participants of anti-terrorist operation with disability due to somatic pathology in technical means of rehabilitation and medical products]. Bulletin of social hygiene and health organization of Ukraine, 2019; 3: 69-77. (In Ukrainian).

14. Pro status veterani 'v vi jni, garanti’ yi yikh soczi al’ nogo zakhistu [0n the status of war veterans, guarantees of their social protection]: Law of Ukraine from 22.10.1993. № 3551-XII. Renewal data: 01.01.2020. URL:https://zakon.rada.gov.ua/laws/show/3551-12. (In Ukrainian).

15. Pro zatverdzhennya Poryadku nadannya ta pozbavlennya statusu uchasnika bojovikh di'j osi 'b, yaki' zakhishhali nezalezhni 'st', suvereni tet ta teritori al 'nu czi'li'sni'st' Ukrayini i’ brali bezposerednyu uchast ${ }^{\prime}$ vantiteroristichni ' joperaczi 'yi, zabezpechenni' yiyi provedennya chi u zdi jsnenni' zakhodi'v i’z zabezpechennya naczi onal 'noyi bezpeki i' oboroni, vi' dsi' chi' i’ strimuvannya zbrojnoyi agresi 'yi Rosi’ js' koyi Federaczi yiv Donecz ki j jta Lugans ' ki j j oblastyakh, zabezpechenni yikh zdi jsnennya [On approval of the Procedure for granting and denying the status of a member of hostilities persons who defended the independence, sovereignty and territorial integrity of Ukraine and participated directly in the anti-terrorist operation, ensuring its carrying out or in the implementation of measures for national security and defense, repulsion and deterrence of the Armed Forces of the Russian Federation in Donetsk and Luhansk regions, ensuring their implementation]: Resolution of the Cabinet of Ministers of Ukraine from 20.08.2014. № 413. Renewal data: 04.03.2020. URL: https://zakon.rada.gov.ua/laws/show/413-2014\%D0\%BF (In Ukrainian).

16. Pro vnesennya zmi'n do deyakikh postanov Kabi 'netu Mi' ni'stri 'v Ukrayini ta viznannya takoyu, shho vtratila chinni 'st', postanovi Kabi 'netu Mi' ni’ stri' v Ukrayini vi’d 12 zhovtnya 2000 r. № 1545 [0n Amendments to Some Resolutions of the Cabinet of Ministers of Ukraine and Recognition as Expired, Resolution of the Cabinet of Ministers of Ukraine of October 12, 2000 No. 1545]: Resolution of the Cabinet of Ministers of Ukraine from 19.02.2020. № 132. URL: https://zakon.rada. gov.ua/laws/show/132-2020-\%D0\%BF\#n283 (In Ukrainian).

17. Pro zatverdzhennya Derzhavnoyi czi'l'ovoyi programi z medichnoyi, fi zichnoyi reabi 'li taczi yi ta psikhosoczi al' noyi readaptaczi yi postrazhdalikh uchasniki 'v Revolyuczi yi Gi'dnosti', uchasniki 'v antiteroristichnoyi operaczi yi ta osi 'b, yaki brali uchast $u$ zdi' jsnenni' zakhodi' vi'z zabezpechennya naczi' onal' noyi bezpeki i’ oboroni, vi dsi' chi 'i strimuvannya zbrojnoyi agresi yi Rosi’ js' koyi Federaczi yi v Donecz' ki j ta Lugans ' ki j joblastyakh, zabezpechenni' yikh zdi jsnennya, na peri' od do 2023 roku [Approval of the State Target Program on Medical, Physical Rehabilitation and Psychosocial Re-adaptation of Victims of the Dignity Revolution, Members of the Anti-Terrorist Operation, and Persons Participated in National Security and Defense, Suppression and Suppression of Armed Aggression in the Russian Federation and Luhansk ensuring their implementation, for the period up to 2023]: Resolution of the Cabinet of Ministers of Ukraine from 05.12.2018. № 1021. Renewal data: 22.10.2019. URL: https://zakon.rada.gov.ua/laws/show/1021-2018-\%D0\%BF (In Ukrainian).

18. Sokrut V.M., Alekseeva L.A. Medichna reabi 'li’ taczi' ya [Medical Rehabilitation]: Guidelines. Liman: Donetsk National Medical University, Ministry of Health of Ukraine, 2016. URL: http://kaf-fis-reab.dsmu.edu. ua/?page_id=445 (In Ukrainian).
19. Pro derzhavni' fi nansovi garanti yi medichnogo obslugovuvannya naselennya [About the state financial guarantees of health care of the population]: Law of Ukraine from 30.01.2018 №2168-VIII. Renewal data:20.03.2020.URL: https://zakon.rada.gov.ua/laws/show/2168-19. (In Ukrainian).

20. Pro zatverdzhennya Polozhennya pro psikhologi' chnu reabi li’ taczi yu vi js' kovosluzhbovczi v Zbrojnikh Sil Ukrayini, ta Derzhavnoyi speczi al' noyi sluzhbi transportu, yaki` brali uchast' v antiteroristichni j operaczi yi, zdi' jsnyuvalizakhodii zzabezpechennyanaczi' onal' noyibezpekii' oboroni, vi dsi' chi' i’ strimuvannya zbrojnoyi agresi yi Rosi' js' koyi Federaczi yi u Donecz ki j ta Lugans 'ki j oblastyakh chi vikonuvali sluzhbovi' (bojovi') zavdannyav vekstremal' nikh umovakh [On approval of the Regulation on the psychological rehabilitation of the military of the Armed Forces of Ukraine and the State Special Transport Service, which participated in the anti-terrorist operation, carried out measures to ensure national security and defense, to repel and deter the armed aggression of the Russian Federation in Donetsk and Luhansk regions ) tasks in extreme conditions]: Order of the Ministry of Defense ofUkrainefrom 09.12.2015 №702. Renewal data: 14.02.2020.URL: https://zakon.rada.gov.ua/laws/show/z0237-16/. (In Ukrainian).

21. Lebedinec N.V., Pliska 0. I., Melnitchenko 0.S., et al. Aktual' ni” pitannya mediko-soczi al 'noyi reabi li’ taczi yi uchasniki v bojovikh di’ j: dosvi'd ta perspektivi. [Topical issues of medical and social rehabilitation of combatants: experience and perspectives]. Scientific and pedagogical problems of physical culture (physical culture and sport): Coll. of sciences. works. Kiev: Publishing in NPU named M. P. Dragomanov, 2019. 2(108): 105-110. (In Ukrainian).

22. Vorona P. V., Gurin A. M. Sistema kompleksnoyi reabi li taczi yi uchasniki 'v antiteroristichnoyi operaczi yi [System of complex rehabilitation of participants of anti-terrorist operation]. Economy and the State. 2019: 4. (In Ukrainian).

23. Shevtchuk V.I., Yavorovenko 0.B., Belyayeva N.M., et al. Organi' zaczi' ya medichnoyi reabi' li’ taczi' yi v provi' dnikh krayinakh svi' tu. [Organization of medical rehabilitation in the leading countries of the world]. Bulletin of problems of biology and medicine, 2019: 2, 1(149): 51-54. (In Ukrainian).

24. Yavorovenko, 0. B., Belyayeva, N. M., Kurylenko, I. V. et al. Potrebi uchasniki v antiteroristichnoyi operaczi yizi 'nvali dni 'styu vnasli dok somatichnoyi patologi 'yi v tekhni' chnikh zasobakh reabi 'li taczi yi ta virobakh medichnogo priznachennya. [Needs of participants of antiterrorist operation with disability due to somatic pathology in technical means of rehabilitation and medical products]. Bulletin of social hygiene and health organization of Ukraine. 2019; 8 (3): 69-77. (In Ukrainian).

25. Pro dodatkovi' zakhodi shhodo soczi al' nogo zakhistu uchasniki v antiteroristichnoyi operaczi yi [On additional measures for social protection of participants of the anti-terrorist operation]: Decree of the President of Ukraine from 18.03.2015 № 150. Renewal data:07.10.2015. URL: http://zakon3.rada.gov.ua/laws/show/150/2015. (In Ukrainian).

26. Pro zatverdzhennya planuzakhodi v shhodo medichnoyi, psikhologi chnoyi, profesi jnoyi reabi 'li taczi yi ta soczi al' noyi adaptaczi yi uchasniki'v antiteroristichnoyi operaczi yi [On approval of the plan of measures for medical, psychological, vocational rehabilitation and social adaptation of participants of the anti-terrorist operation]: Ordinance of the Cabinet of Ministers of Ukraine from 31.03.2015. № 359-p. URL: https://zakon.rada. gov.ua/laws/show/359-2015-\%D1\%80. (In Ukrainian).

27. Osnovi zakonodavstva Ukrayini pro okhoronu zdorov'ya [Fundamentals of Ukrainian legislation on health care]: Law of Ukraine from 19.11.1992 №2801-XII. Renewal data:02.04.2020. URL: https://zakon.rada.gov.ua/ laws/show/2801-12. (In Ukrainian). 
28. Marunich V.V., Shevtchuk V.I., Yavorovenko O.B. Metodichnij posi bnik z pitan ' reabi li taczi yi i nvali di v [A handbook on disability rehabilitation]:.Vinnitsa: Ukrainian State Research Institute of Disabled Rehabilitation; 2006, 210 p. (In Ukrainian).

29. Ustinov 0.V. Medichna reabi li’ taczi ya: potochna situaczi ya i’ plani na majbutnye. [Medical Rehabilitation: Current Situation and Future Plans]. Ukrainian Medical Journal online. URL: https://www.umj.com. ua/article/119087/zatverdzheno-plan-zahodiv-iz-vprovadzhennyamizhnarodnoyi-klasifikatsiyi-funktsionuvannya. (In Ukrainian).

30. Ustinov 0.V. Medichna reforma: prijnyato nizku vazhlivikh normativnikh dokumenti v. [Medical reform: A number of important regulatory documents have been adopted]. Ukrainian Medical Journal online. URL: https://www.umj.com.ua/article/167302/medichna-reformaprijnyato-nizku-vazhlivih-normativnih-dokumentiv. (In Ukrainian).

31. Pro zatverdzhennya ta vprovadzhennya mediko-tekhnologi chnikh dokumenti`v zi` standartizaczi`yi medichnoyi dopomogi pri posttravmatichnomu stresovomu rozladi' [On approval and introduction of medical-technological documents on standardization of medical care in post-traumatic stress disorder]: Order of the Ministry of Health of Ukraine from 23.02.2016 №121 URL: https://ips.ligazakon.net/ document/view/moz25625. (In Ukrainian).

32. Pro zatverdzhennya pereli ki `v medichnikh pokazan ` ta protipokazan` do sanatornogo li’ kuvannya i’ medichnoyi reabi' li taczi yi v sanatornokurortnikh zakladakh Zbrojnikh Sil Ukrayini [0n approval of the lists of medical indications and contraindications to sanatorium treatment and medical rehabilitation in sanatorium-resort establishments of the Armed Forces of Ukraine]: Order of the Ministry of Defense of Ukraine from 09.12.2015 № 703. URL: https://zakon.rada.gov.ua/laws/show/ z1681-15. (In Ukrainian).
The work is a fragment of SRR "Medical and social rationale for optimizing approaches to managing and organizing various types of medical care for adults and children in the period of reforming the health care industry" (№ St. Registered 0119U102926 term of performance 2018-2022 year).

ORCID and contributorship:

Vyacheslav M. Zhdan - 0000-0002-4633-5477 A,D,E,F

Oleksandr D. Havlovskyi - 0000-0002-0310-0766 ${ }^{\text {B,E,F }}$

\section{Conflict of interest:}

The Authors declare no conflict of interest.

\section{CORRESPONDING AUTHOR Oleksandr D. Havlovskyi}

Ukrainian Medical Stomatological Academy

st. Shevchenko 23, 36000 Poltava, Ukraine

tel: +380675302875

e-mail: skk@mirgorodkurort.com.ua

Received: 04.03 .2020

Accepted: 07.05.2020 